\title{
The Master and His Manuscript
}

\author{
Karolína Stehlíková
}

Jan Holmberg. Forfätteren Ingmar Bergman. Norsteds, 2018. 289 pp.

The year 2018 being Ingmar Bergman's centenary was a perfect occasion not only to screen Bergman's films and organize various events to remember this remarkable auteur but also to publish essays, books and organise conferences to stimulate academic thinking about his work. From $14^{\text {th }}$ to $16^{\text {th }}$ June 2018 , the University of Lund (Sweden) hosted a conference Ingmar Bergman: 100 Years. The event brought together some of the leading scholars such as the British film historian Peter Cowie, Thomas Elsaesser from Germany or Maaret Koskinen from Sweden, who have been studying Bergman's work for years. One of the speakers was also Jan Holmberg, the CEO of The Ingmar Bergman Foundation. In his lecture 'Cinema as Detour' (which Czech translation is also published in this issue of Theatralia), he provokingly stated that Bergman the writer might outlive Bergman the filmmaker. Jan Holmberg based this bold statement on his thorough study of all the texts Ingmar Bergman has ever written, may it be scripts, workbooks, essays, novels, letters, diaries or various notes. He also went through many secondary materials such as interviews or reviews of Bergman's books, not to mention the texts scrutinizing Bergman's writing on an academic basis.

In 2018, Holmberg's work led to publishing the book Forfättaren Ingmar Bergman [Ingmar Bergman, The Writer]. It is a beautifully looking monograph with all-cloth red cover dominated by a silhouette standing in front of the handwritten text. The whole book is introduced by two quotations, both concerning the fact that Shakespeare's plays were written mainly for stage not for print. The authors of these two comments are J. W. Goethe and Bob Dylan. Goethe probably intended to emphasise the difference between his generation of writers bound by classicist rules and the Elizabethan master, who mainly considered the theatre practice when writing his plays. Dylan sees himself as being in the same role as Shakespeare. His lyrics should also be sung and not read. These two mottos anticipate the main research question Jan Holmberg asks himself. The inquiry is plain and simple: 'Is Ingmar Bergman a writer?' This question is asked on purpose. Bergman himself has many times stated he is a very poor writer (or refused to be perceived as a writer at all) and that everything he has ever written is 'halvfabrikat' - a semi-product or a score (some of his scripts even have a subtitle, which implicates the semi-product nature of the text). Jan Holmberg goes a very long and elaborated way to uproot this myth. Setting Bergman's diverse texts into the detailed context of his writing habits, his variable self-esteem, places and institutions he worked for, his position in the Swedish literary field, his momentary mental health, his growing success as a filmmaker and other factors, Holmberg 
comes to the affirmative answer. Holmberg also proves that Bergman belongs to authors who write because of their inner urge, which often turns to the automatic or unconscious writing.

Before we explore the structure of the reviewed book, it should be said that Homberg has tried to look away from Bergman's films and wanted 'above all to avoid perceiving them as results of the process where its parent texts are reduced to be only the drafts' (11). It works, even though the author has to remind us of this perspective throughout the whole book. It is necessary because a reader who knows Bergman well is usually well aware of his attitude to his texts and tends, of course, to perceive him the way Bergman manipulates us - as a writing filmmaker. Holmberg also states that he is very suspicious when it comes to what Bergman says about his own texts. It is this feature which helps Holmberg to discover certain unexpected connections and uproot some myths.

The book is divided into six chapters. The first one is devoted to Bergman's writing habits and the role his handwriting plays in what and how he writes. The reader learns that the outer form of Berman's scripts was from the beginning influenced by the type of two columned notebooks he received when he worked as a scriptwriter and editor in the production company Svensk Filmindustri in the 1940s. We also learn that he wrote by hand his whole life (always having a wife or a woman assistant ready to rewrite his manuscripts on the typewriter). And that his handwriting strikingly resembles the one of his great predecessor and lifetime inspiration August Strindberg. Holmberg also explains that Bergman has written two types of diaries - diaries designed for the public (these has been published in Swedish under the title Tre dagböcker and are actually mirroring the fight Bergman's last wife led with cancer) and the real diaries which will be released to public in 2055 for the first time. Without revealing anything, Holmberg describes the nature of these diaries. We should not expect any breakthrough discoveries since the diaries, according to Holmberg, contain mostly very brief and concise observations regarding the everyday life (e.g. sleep, health or weather). Then there are autobiographical works such as Laterna Magica and My Life in Film (published in Sweden in 1987, respectively 1990).

Here, Holmberg makes one observation, which he will then develop in the next chapters - in Bergman's texts the line between fiction and autobiography is very thin, as thin that it is sometimes completely vanishing (not to speak about motifs from Strindberg's plays which often infiltrate Bergman's writing). In the chapters devoted to Bergman writing for film, Bergman writing memoirs and Bergman writing novels, Holmberg reveals how Bergman freely uses his real experiences (or what he presents to be his real experience) both in his fiction and autobiographical writing (often using identical words and sentence structures). Why is he doing it, asks Holmberg? Holmberg reveals yet another interesting feature of Bergman's writing, next to the fictionalization of his autobiographic works, e. g. his subversive practice of interviewing himself by dividing his persona into two people having different roles (for example the roles of art director and economy director in the theatre). On the top of this game is the well-known of the Swedish article for an antiBergman issue of Swedish film magazine Chaplin from 
1960, where Bergman under the pseudonym Ernest Riffe criticized his own work. No wonder that even Bergman's usage of pronouns is very tricky as Holmberg analyses throughout the whole book.

In the second chapter called 'Forfätteren?' [Writer?], Holmberg traces the moment when Bergman becomes recognised as an author. The reader learns that in 1946 and 1948 Bergman published four plays. They were received rather well, the critics giving the promising young author mostly positive feedback. However, Bergman for various reasons was not satisfied with it. Bergman's own rejection of being perceived as a writer coincides with his success as a filmmaker in the $1950 \mathrm{~s}$. According to Holmberg, Bergman does not retreat from the literary scene, his writing for film should be understood more as an offensive. With writing scripts, Bergman discovers for himself a new genre (to which he adds many special features, or we can say that he will continuously adapt it to his needs). Most of his scripts are sooner or later going to transform into a film. However, unless they are published, they are almost private. No literary critic can analyse, evaluate or attack them. Since the 1950 s, Bergman views himself as one of the anonymous workers (not artists) creating a work of God - like workers building the cathedral in Chartres (see Bergman's essay 'The Making of Film' from 1954) or one of the ants moving the empty snakeskin (a metaphor he uses in his essay 'Snakeskin' from 1965). These statements can be interpreted as an expression of great humbleness or maybe - as Holmberg will point out later - a huge overbearance.

The chapter three 'Filmforfätteren' [Film writer] looks closely into the nature of Bergman's scripts as well as at the term filmberättelser ('film stories' in English). Holmberg closely scrutinizes some of the scripts, which are interesting in terms of various features distinguishing them from film scripts of more technical nature. Looking at the scripts of Persona, The Hour of Wolves, Autumn Sonata, he analyses how close they are to poetry, novel or drama, and how some of them are influenced by music. He also reveals the genesis of Bergman's film scripts being published (for the first time they were surprisingly published in English by Simon\&Schuster under the title Four Screenplays in 1960). Like Milan Kundera, Ingmar Bergman refused to publish his texts in his native language. Four Screenplays were thus translated in languages like Italian, French, German, Polish (among many others, and later also into Czech). Finally, in 1963 Bergman signed an agreement with the publishing house Norsteds and so the book En film trilogi was published in the same year. Since then, Bergman was published regularly in Swedish (the list of Bergman's books in Swedish is to be found at the end of the book, containing 22 entries).

In chapter four and five, Holmberg explores Bergman as a novel writer and memoir writer. When coming to his late texts, Holmberg points out how Bergman slows down the tempo of the story's narration. When reading Holmberg's analysis of Saraband, one is reminded of one of the last albums by Leonard Cohen which also subjectifies slowness (the song Slow with the lyrics 'I always liked it slow'). In chapter six, Holmberg pictures the last days of Bergman the writer - with his ability to write eventually completely vanishing. He presents here an interesting observation: what Bergman said about himself and his writing was actually earlier summarised 
in a fairy tale of H. C. Andersen called Andersen's and Bergman's texts? This is Pen and Inkstand (Who knows if Bergman another wily question Holmberg asks.

knew it. But it is not impossible since it was In his book, Jan Holmberg, thanks to translated into Swedish by August Strind- his thorough analysis, confirms what one berg as Holmberg points out). This fairy might already suspect watching the prolific tale is an argument between the pen and second life of Bergman's texts on theatre the inkstand regarding the authorship. stages: Ingmar Bergman was a filmmaker, It ends with Latin saying Soli Deo Gloria theatre director and yes, indeed, a writer; [Glory to God alone], the saying Bergman and thanks to Holmberg's highly readable also once added to the end of the script of and well composed book, we now know Winter Light. Yet, who is the God both in that a very exceptional one. 